\title{
Formation of Leukotrienes From Calcium Ionophore-A23187 Stimulated Rabbit, Rat and Mice White Blood Cells
}

\author{
Mahmoud A. Mansour ${ }^{1 *}$, Fahad I. Al-Jenoobi ${ }^{2}$, Saleh A. Al-Suwayeh ${ }^{2}$, Abdulhakeem A. Al- \\ Majed' and Othman Al-Shabanah' \\ Department of Pharmacology ${ }^{1}$ and Department of Pharmaceutics ${ }^{2}$. College of Pharmacy King \\ Saud University. P. O. Box 2457, Riyadh 11451, Saudi Arabia.
}

\begin{abstract}
Leukotrienes (LTs) producing capacity was investigated in calcium ionophore A23187stimulated rabbit. rat and mice peripheral white blood cells suspension. A reverse phase high performance liquid chromatography technique and computerized UV spectroscopy were employed to isolate and quantitate the released LTs namely, $\mathrm{LTC}_{4}$ and $\mathrm{LTB}_{4}$. Preincubation of rabbit white blood cells at $37^{\circ} \mathrm{C}$ for 5 min followed by calcium ionophore-A23187 (1 $\left.\mu \mathrm{M}\right)$ stimulation for another 5 min produced an equal amounts of $\mathrm{LTC}_{4}$ as compared to $\mathrm{LTC}_{4}$ produced by human white blood cells $\left(105 \pm 11\right.$ versus $95 \pm 9.5 \mathrm{pmol} / 10^{7}$ cells respectively; mean \pm SEM). In contrast rabbit white blood cells synthesized significantly lower $\mathrm{LTB}_{4}$ in comparison with $\mathrm{LTB}_{4}$ produced by peripheral white blood cells from healthy control $\left(168 \pm 18\right.$ versus $228 \pm 19 \mathrm{pmol} / 10^{7}$ cells respectively; mean \pm SEM). When rat and mice white blood cells suspension were stimulated with calcium ionophore A23187 $(1 \mu \mathrm{M})$ after preincubation at $37^{\circ} \mathrm{C}$ for $5 \mathrm{~min}$, equivalent amounts of $\mathrm{LTC}_{4}$ and $\mathrm{LTB}_{4}$ were observed. However, $\mathrm{LTB}_{4}$ and $\mathrm{LTC}_{4}$ produced by rat and mice white blood cells were significantly lower in comparison with $\mathrm{LTB}_{4}$ and $\mathrm{LTC}_{4}$ produced by human white blood cells stimulated with calcium ionophore-A23187. These results demonstrate that rabbit. rat and mice white blood cells suspension possess the capacity to produce $\mathrm{LTC}_{4}$ and $\mathrm{LTB}_{4}$ from endogenous substrate after calcium ionophore-A23187 stimulation.
\end{abstract}




\section{Introduction}

Leukotrienes are a family of oxygenated metabolities of arachidonic acid, which synthesized by 5-lipoxygenase enzyme (EC 2.5.1.18) ${ }^{1}$. During cell activation, LTs biosynthesis is initiated by translocation of a specific high molecular weight cytosolic phospholipase $\mathrm{A}_{2}\left(\mathrm{cPLA}_{2}\right)$ from cytoplasm to selectively hydrolyze nuclear envelope phospholipids releasing arachidonic $\mathrm{acid}^{2}$. The liberated arachidonic acid binds to arachidonate transfer protein, 5-lipoxygenaseactivating protein (FLAP) which makes the fatty acid available to 5-lipoxygenase enzyme $\mathrm{e}^{3.4}$. In a calcium-and ATP-dependent reaction the fatty acid is transformed to unstable epoxide intermediate leukotriene $\mathrm{A}_{4}\left(\mathrm{LTA}_{4}\right)^{5.6}$. In various human cell types and tissues, leukotriene $\mathrm{A}_{4}$ is metabolized via three main pathways; by cytosolic $\mathrm{LTA}_{4}$ hydrolase (EC 3.3.2.6) to the potent leukocyte activator, $\mathrm{LTB}_{4}{ }^{7}$ or by membrane bound $\mathrm{LTC}_{4}$ synthase (EC 2.5.1.37) to the spasmogenic cysteinyl containing leukotriene viz $\mathrm{LTC}_{4}{ }^{8}$ or spontaneously non-enzymaticaly hydrolysed to the biologically inactive stereoisomers namely; 6-trans $\mathrm{LTB}_{4}$ and 12-epi-6trans $\mathrm{LTB}_{4}{ }^{9}$. Endogenous and exogenous stimuli including platelet activating factor, chemotactic peptide $\mathrm{C} 5 \mathrm{a}$ and calcium ionophore A23187 have been shown to trigger the release of $\mathrm{LTs}^{10}$.

LTC $_{4}$ once formed is exported from the cells via an active transport to the extra-cellular space ${ }^{\mathrm{II}}$. The subsequent conversion of $\mathrm{LTC}_{4}$ into $\mathrm{LTD}_{4}$ via removal of $\gamma$-glutamyl moiety from glutathione is catalyzed by $\gamma$-glutamyl-transpepetidase, an enzyme located at the external site of plasma membrane ${ }^{12}$. This reaction can not be considered as biological inactivation. since $\mathrm{LTD}_{4}$ generally possess equal or even higher potency than $\mathrm{LTC}_{4}{ }^{13}$. The next metabolic step results in substantially loss of the biological activity through removal of glycine results in $\mathrm{LTE}_{4}$ formation. The cysteinyl-containing leukotrienes bind to specific receptors and mediate a wide variety of inflammatory response ${ }^{14}$. In the airway system. $\mathrm{LTC}_{4}$ is one of the relevant mediators involved during bronchial asthma and is responsible for many 
of the cardinal symptoms of the disease ${ }^{15}$. It increases mucus secretion, edema formation and being a potent spasmogenic ${ }^{16}$. The cysteinyl-containing leukotrienes receptors antagonists are now in clinical use for pharmacological treatment of these diseases ${ }^{17}$

A key pro-inflammatory role has been postulated for $\mathrm{LTB}_{4}$ in the light of its ability to recruit and activate inflammatory cells ${ }^{18}$. It stimulates the production of a number of proinflammatory mediators including cytokines ${ }^{7}$, release of lysosomal enzymes ${ }^{19}$, the generation of superoxide radicals in neutrophils ${ }^{20}$, as well as it activates NADPH oxidase (EC 1.6.99.1) of human eosinophil and $\mathrm{H}_{2} \mathrm{O}_{2}$ production by human monocytes ${ }^{21}$. These effects reflect an ability to accentuate free radicals generation and indicating an ability to augment and prolong tissue inflammation.

The knowledge concerning leukotrienes biosynthesis by white blood cells of different species is limited. Previously it has been demonstrated that calcium ionophore-A23187 induced $\mathrm{LTB}_{4}$ generation from rabbit and rat white blood cells ${ }^{22}$. However $\mathrm{LTC}_{4}$ formation has not been described.

The goal of the present study was to extend the previous observations to study the capacity of white blood cells from different species rabbit, rat and mice to produce $\mathrm{LTB}_{4}$ and $\mathrm{LTC}_{4}$. To achieve this goal, white blood cells from rabbit, rat and mice were isolated and stimulated with calcium ionophore-A23187 to produce $\mathrm{LTB}_{4}$ and $\mathrm{LTC}_{4}$ in comparison with $\mathrm{LTB}_{4}$ and $\mathrm{LTC}_{4}$ produced by peripheral white blood cells from the healthy donors were investigated.

\section{Materials and Methods}

\section{$\underline{\text { Materials }}$}

The following chemicals were used: calcium ionophore-A23187, LTB 4 and $\mathrm{LTC}_{4}$ (Sigma Chemical Company, St. Louis, MO. USA); dextran T500 and ficoll (Pharmacia. Freiburg. Germany): phosphate buffer saline (PBS): Dulbecco`s formulation containing $0.9 \mathrm{mM}$ calcium. pH 7.4 (Gibco BRL. Life Science Technologies Ltd.. Paisley. Scotland): HPLC 
columns (Beckman, San Roman. California, USA) and HPLC solvents (E. Merck, Darmstadt, Germany). The remaining reagents were of the highest analytical grade available.

\section{Animals Experiments:-}

White rabbit, swiss albino rats and normal mice were obtained from Experimental Animal Care Center of King Saud University, Riyadh, Saudi Arabia. They were housed in a room maintained at a temperature of $24 \pm 1^{\circ} \mathrm{C}$ and $55 \pm 5 \%$ relative humidity with a regular $12 \mathrm{~h}$ light: $12 \mathrm{~h}$ dark cycle and free access to standard laboratory food (Purina Chow) and water.

\section{Preparation of white blood cells suspension}

Blood samples from the rabbit, rats and mice as well as from healthy controls were taken into heparinized tubes. The white blood cells were separated following standard laboratory technique ${ }^{23}$. Briefly, $10 \mathrm{ml}$ of whole blood was mixed with an equal volume of dextran T500 ( $2 \%$ in saline), then, allowed to stand for $30 \mathrm{~min}$ at $4{ }^{\circ} \mathrm{C}$ to sediment erythrocytes. The leukocytes-rich upper plasma layer was then aspirated and centrifuged at $280 \mathrm{xg}$ for $10 \mathrm{~min}$. The resultant leukocyte pellet was washed twice with PBS then, re-suspended in $20 \mathrm{ml}$ of hypotonic ammonium chloride $(0.74 \%$ in $\mathrm{PBS})$ for another $30 \mathrm{~min}$ at $4^{\circ} \mathrm{C}$ to lyse any remaining erythrocytes. After centrifugation at $280 \mathrm{xg}$ for $10 \mathrm{~min}$, the cell pellets were washed twice and suspended in PBS. The cells were counted in a Neubauer counting chamber. The final white blood cell counted was adjusted at $10 \times 10^{6}$ cells $/ \mathrm{ml}$ PBS. The viability was about $95 \%$ as judged by trypan blue exclusion test.

\section{Incubation procedure:}

Human, rabbit, rat and mice white blood cells $10 \times 10^{6}$ cells/ml PBS were incubated at $37^{\circ} \mathrm{C}$ for 5 min. After pre-incubation, the cells were immediately stimulated for the release of LTs with calcium ionophore-A23187 (Final concentration $1 \mu \mathrm{M}$ ) $1 \mu \mathrm{l}$ of calcium ionophoreA23187 $(1 \mathrm{mM})$ was added to each aliquote $(1 \mathrm{ml})$ to give final concentration of $1 \mu \mathrm{M}$. The release reaction was terminated after $5 \mathrm{~min}$ by adding 5 volumes of $99 \%$ ethanol and placing the tubes in ice. The samples were stored at $-20^{\circ} \mathrm{C}$ until required for further processing. 


\section{Purification, Identification and Quantitation of leukotrienes: -}

The samples dissolved in ethanol were centrifuged and the clear supernatants were aspirated and then evaporated to dryness. The obtained residues were dissolved in mobile phase and then centrifuged. Identification and quantitation of leukotrienes were performed by RP-HPLC and UV spectroscopy, as previously reported ${ }^{24}$. Chromatographic separation was performed at room temperature using Shimadizu programmable module apparatus (Japan) and a mobile phase consisting of acetonitrile/methanol/water/acetic acid (30:19:50:0.8, $\mathrm{pH} 5.6)$. The absorbance of the effluent was continuously monitored at $280 \mathrm{~nm}$ using a variable wavelength UV detector. Authentic standard of LTs was co-chromatographed with the samples for the identification and quantitation of the eluted LTs in the samples. The areas under the curve of each type of LTs in the samples were correlated with that of the standard. The results were expressed as $\mathrm{pmol} / 10^{7}$ cells.

\section{Statistics}

Data are expressed as (means \pm SEM). Statistical comparisons of leukotrienes production in suspension of rabbit, rat and mice white blood cells and human white blood cells were performed by using student's $t$-test. Significance was accepted at $\mathrm{P}<0.05$.

\section{Results}

Leukotrienes formation in suspension of human and rabbit white blood cells.

When human and rabbit white blood cells were stimulated with $1 \mu \mathrm{M}$ calcium ionophoreA23187 for 5 min. a release of 5-lipoxygenase derived products viz. $\mathrm{LTC}_{4}$ and $\mathrm{LTB}_{4}$ can be identified. $\mathrm{LTB}_{4}$ was the major compound formed. Rabbit white blood cells produced an equivalent amount of $\mathrm{LTC}_{\downarrow}$ as compared to that produced by peripheral white blood cell separated from the control healthy donor. Thus, $105 \pm 11(n=8 ;$ mean \pm SEM) and $95 \pm 9.7$ 
$(n=4)$ pmol LTC $\mathrm{LT}_{\downarrow} / 10^{7}$ cells were produced by rabbit white blood cells and white blood cells separated from healthy controls respectively (Fig 1). However, the production of $\mathrm{LTB}_{4}$ was significantly lower in rabbit white blood cells suspension as compared to the human white blood cells. Thus, $168 \pm 18$ versus $228 \pm 19$ pmol LTB $4 / 10^{7}$ cells were produced by rabbit and human white blood cell suspensions respectively (Fig 1).

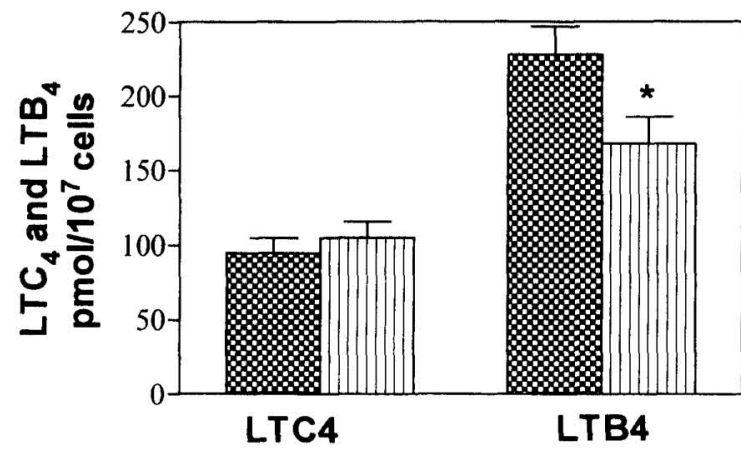

Human white blood $\square$ Rabbit white blood

Fig (1): Leukotrienes formation by rabbit and human peripheral white blood cells suspension stimulated with calcium ionophore-A23187.

Peripheral white blood cells separated from rabbit and control healthy donors $\left(10 \times 10^{6} / \mathrm{ml}\right.$ PBS) were preincubated at $37^{\circ} \mathrm{C}$ for $5 \mathrm{~min}$, then stimulated with $\mathrm{A} 23187(1 \mu \mathrm{M})$ for leukotriene release for another $5 \mathrm{~min}$. The reaction was terminated by addition of $5 \mathrm{ml}$ of ethanol $99 \%$ and placing the tube in ice. Leukotrienes were identified and quantified by RPHPLC.

\section{Leukotrienes formation in suspension of human, rat and mice white blood cells.}

Rat and mice white blood cells preincubated at $37^{\circ} \mathrm{C}$ for $5 \mathrm{~min}$ and stimulated with calcium ionophore-A23187 for another $5 \mathrm{~min}$, produced a similar amounts of $\mathrm{LTC}_{4}$ and $\mathrm{LTB}_{4}$. However, stimulation of white blood cells separated from healthy donor produced $\mathrm{LTC}_{4} 5$ times more than $\mathrm{LTC}_{4}$ produced from rat and mice (Fig 2). In addition, human white blood cells produced 5 and 7 times $\mathrm{LTB}_{4}$ as compared to $\mathrm{LTB}_{4}$ produced from rat and mice, respectively (Fig 2). 


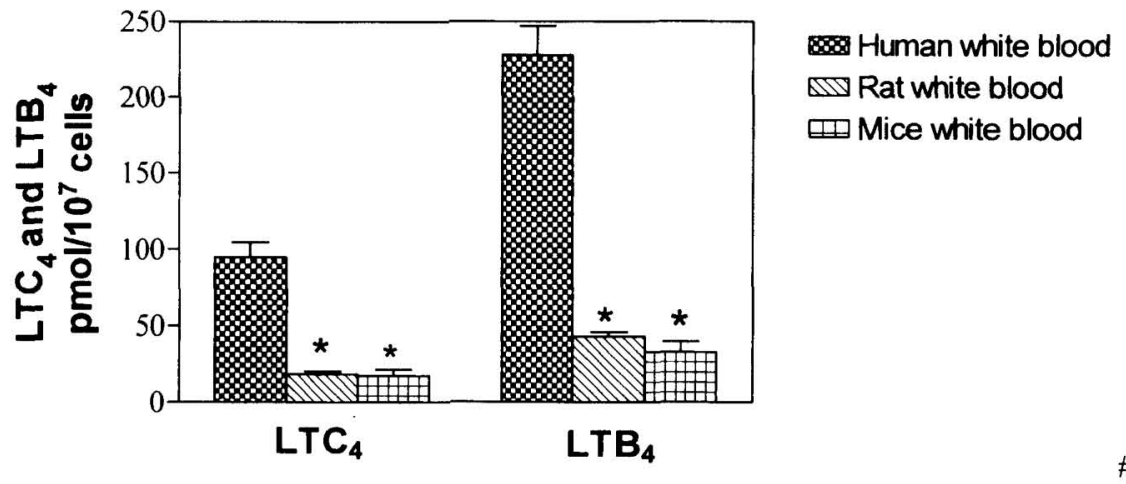

Fig (2): Leukotrienes formation by rat, mice and human peripheral white blood cells suspension stimulated with calcium ionophore-A23187.

Peripheral white blood cells separated from rat, mice and control healthy donors (10 $\mathrm{x} 10^{6} / \mathrm{ml}$ PBS) were preincubated at $37^{\circ} \mathrm{C}$ for $5 \mathrm{~min}$, then stimulated with $\mathrm{A} 23187(1 \mu \mathrm{M})$ for leukotriene release for another $5 \mathrm{~min}$. The reaction was terminated by addition of $5 \mathrm{ml}$ of ethanol $99 \%$ and placing the tube in ice. Leukotrienes were identified and quantified by RPHPLC

\section{Discussion}

Stimulation of human white blood cells with calcium ionophore-A23187 $(1 \mu \mathrm{M})$ led to the generation of leukotrienes, predominantly $\mathrm{LTB}_{4}$ which is known as the major mediator released from human leukocytes ${ }^{25}$. By virture of its calcium ionopheric property, A23187 produces an elevation of intracellular calcium concentration that is required for the binding of 5 -lipoxygenase to an activating protein (FLAP) ${ }^{3}$. This binding activates enzyme results in its association with the nuclear membrane and consequently increases the synthesis of LTs from arachidonic $\operatorname{acid}^{26.27}$.

The present study showed that, rabbit, rat and mice white blood cells suspension possess the capacity to produce $\mathrm{LTC}_{+}$and $\mathrm{LTB}_{4}$ after calcium ionophore-A23187 stimulation. This finding indicates that calcium ionophore A23187 activates 5-lipoxygenase enzyme in white blood cells isolated from rabbit, rat and mice and the stimulus is sufficient to make endogenous arachidonic acid available for leukotrienes synthesis in these cells. 
The results of the present study demonstrate that rabbit white blood cells produced an equivalent amount of $\mathrm{LTC}_{4}$ as compared to human peripheral white blood cells. In contrast, the synthesis of $\mathrm{LTB}_{4}$ was significantly lowered in rabbit white blood cells suspension as compared with $\mathrm{LTB}_{4}$ produced by human white blood cells (Fig. 1). Stimulation of rat and mice white blood cells suspensions produced similar amounts of $\mathrm{LTC}_{4}$ and $\mathrm{LTB}_{4}$. However, $\mathrm{LTC}_{4}$ produced from calcium ionophore-A23187 stimulated human white blood cells was 5 times more than $\mathrm{LTC}_{4}$ produced by rat and mice white blood cell suspension. In addition human white blood cells produced 5 and 7 times $\mathrm{LTB}_{4}$ more than $\mathrm{LTB}_{4}$ produced from white blood cells separated from rat and mice respectively.

The present results are consistent with the previous study demonstrated that rabbit and rat white blood cells produced $\mathrm{LTB}_{4}$ from endogenous arachidonic acid after calcium ionophoreA23187 $(1 \mu \mathrm{M})^{22}$

White blood cells suspension contains heterogeneous cells populations mainly neutrophils which produce $\mathrm{LTB}_{4}{ }^{28}$, while esinophils and basophils produce $\mathrm{LTC}_{4}{ }^{29}$. In addition, it has been shown that B-lymphocytes produce leukotrienes only when stimulated with calcium ionophore-A23187 in the presence of exogenous arachidonic acid and reducing agents ${ }^{30}$. Thus, in the present study, $\mathrm{LTB}_{4}$ and $\mathrm{LTC}_{4}$ were produced by neutrophils and eosinophils respectively. However, when studying in vitro leukotrienes producing capacity, samples containing identical number of the cells and a similar percentage of different cell types should be compared. Therefore, it has been assumed that the decreased level of $\mathrm{LTC}_{4}$ and $\mathrm{LTB}_{4}$ produced by rat and mice white blood cells suspension in the present study may be due to the difference in the percentage of various cell types in comparing with human white blood cell suspensions. In the present study, differential cell identification count revealed that there was no significant difference between number of neutrophils, eosinophils and mononuclear cells in the different white blood cells suspensions (data not shown). 
The reason why the rat and mice cells produced significantly lowered $\mathrm{LTC}_{4}$ and $\mathrm{LTB}_{4}$ as compared to human white blood cells may be due to decreased arachidonic acid content in phospholipid of nuclear envelope of white blood cells of rat and mice. Thus less of the substrate (arachidonic acid) will be available for 5-lipxygenase enzyme. In addition, the identity of the specific phospholipase $\mathrm{A}_{2}$ involved in the release of arachidonic acid utilized for leukotrienes synthesis is still a matter of controversial between different species ${ }^{31}$. Moreover it has been demonstrated that leukotrienes synthesis in intact cells from various species depend on the activity of 5-lipoxygenase-activating protein (FLAP), which binds arachidonic acid, thereby facilitating the 5-lipoxygenase-catalyzed conversion of fatty acid into $\mathrm{LTA}_{4}{ }^{4.32}$. These may indicate a difference in the level of arachidonic acid content or difference in 5-lipoxygenase activating protein level in rat and mice as compared to human white blood cells.

In conclusion: This investigation demonstrates that white blood cells of rabbit, rat and mice possess the capacity to produce different amounts of leukotrienes from endogenous substrate after short term incubations with calcium ionophore-A23187.

\section{References}

1. Samuelsson B., (1987), Drug 33 (suppl. 1): 2

2. Mayer R. J., and Marshall L. A., (1993), FASEB J 7: 339

3. Reid G. K., Kargman S., Vickers P., Mancini J. A., Lévéille C., Ethier D., Miller G., Gillard J. W., Dixon R. A., Evans J. (1990), J. Biol. Chem. 265: 19818

4. Abramovitz M., Wong E., Cox M. E., Richardson C. D., Li C., Vickers P. J. (1993), Eur. J. Biochem. 215: 105

5. Ford-Hutchinson A. W.. Gresser M., Yang R. (1994), Annun. Rev. Biochem. 63: 383

6. Peters-Golden M (1998), Am. J. Resp. Crit. Care Med. 157 :s227

7. Ford-Hutchinson A W. (1990), Crit. Rev. Immunol. 10: 1 
8. Lam B. K, Gagnon L., Austen K. F., Soberman J. (1990), J. Biol. Chem. 265(23): 13438

9. Samuelsson B., Dahlén S-E., Lindgren J. Å., Rouzer C. A., Serhan C. N. (1987), Science 237: 1171

10. Tanizawa H., and Tai H. H. (1989), Biochem Pharmacol. 38: 2559

11. Lam B. K., Owen Jr. W., Austen, K F., Soberman R J. (1989), J. Biol. Chem. 264: 12885

12. Tsao B. and curthoys N P. (1980), J. Biol. Chem. 255: 7708

13. Lewis R., Drazen J M., Austen K F., Toda M., Brion F., Marfat A., Corey E. (1981), Proc. Natl. Acad. Sci (USA) 78: 4579

14. Krell R D., Aharony D., Bucker C K., Kusner J. (1990), Adv. Prostaglandin Thromboxane leukotriene Res. 20: 119

15. Samuelsson B. (1983), Science 220: 568

16. Holroyde M C., Altounyan R E., Cole M., Dixon M., Elliotte E V.(1981), Lancet 2(8236): 17

17. Classen H-E and Dahlén S-E (1999), J. Int. Med. 245:205

18. Henderson W.R. (1994), Ann. Intern. Med. 121: 684

19. Palmblad J., Malmsten C., Uden A-M., Rådmark O., Engstedt L., and Samuelsson, B. (1981), Blood 58:658

20. Serhan C. N., Radin A., Smolen J. E., Chorchake H., Samuelsson B., Weissmann G (1982), Biochem. Biophys. Res. Commun. 107: 1006

21. Crooks S. W. and Stockley R. A. (1998), Int. J. Biochem. Cell Biol. 30:173

22. Lindberg $\AA$., Tornhamre S., Mugnai S., Lindgren J $\AA$ (1998), Biochem. Biophys. Acta 1391: 247

23. Bøyum A. (1968), Scand. J. Clin. Lab. Invest. 21: 77 
24. Stenke L., Samuelsson J., Palmblad J., Dabrowski L., Reizenstein P., Lindgren J $\AA$ (1990), Brit. J. Hematol. 74: 257

25. Ford-Hutchinson A. W., Bray M. A., Doig M. V., Shipley M., Smith J. (1980), Nature 286: 264

26. Palmer R. M., and Salmon J. A (1983), Immunology 50: 65

27. Sigal E. (1991), Amer. J. Physiol. 260: L13

28. Borgeat P. and Samuelsson B. (1979), J. B101. 254: 2643

29. Shaw R J., Crowell O. Kay A B. (1987), Clin. Exp. Immunol. 56:716

30. Jakobsson P., Shaskin P., Larsson P., Feltenmark S., Odlander B., Aguilar-Santelises M., Jondal M., Biberfeld P., Classon H.-E (1995), Eur. J. Biochem. 232:37

31. Marshall A., Bolognese B., Winkler J. Roshak A. (1997), J. Biol. Chem. 272:759

32. Mancini J A., Abramovitz M., Cox M E., Wong E., Charleson S., Perrier H., Wang Z., Prasit P., Vickers P. (1993), FEBS Lett 318: 277 